\title{
Local Governance and Development Communication: A Case Study of Gram Panchayat from Cooch Behar District in West Bengal, India
}

\author{
Anil Kumar Biswas*
}

\begin{abstract}
Local governance as an institution of local administration establishes the crucial significance in participation of people in the management and administration of their local affairs through their periodically elected representatives/leaders and their own frequent involvement in the formulation and implementation of development plans for their locality. Local governance is also working as an institution of communication channel between elected leaders and common people. So, it is important to note that the concept of people's participation in local governance is of great significance for the successful functioning of a local authority by creating space for communication between leaders and mass. Due to large size of a Gram Panchayat area and population West Bengal introduced Gram Sansad as grassroots institution by amending West Bengal Panchayat (Amendment) Act in 1994. For the study researcher purposively selected 11 Gram Sansads of Rampur I Gram Panchayat from Cooch Behar district of West Bengal for the study of the nature of developmental communication and understanding on rural politics. The work is based on primary and secondary data. This research seeks to outline the performance of people participation in Gram Sansad and to examine the nature of communication between leaders and mass and making an understanding on rural politics. It is an attempt not merely to identify the shortcomings of the Gram Sansad, but also to examine it as a tool for rural development and understanding on rural politics through communication channel between mass and leaders and also suggests some measures for increasing people participation and interaction between mass and leaders in the grass root institution for the success of participatory development.
\end{abstract}

KEYWORDS: Participation, Development, Communication, Governance, Institution

\section{INTRODUCTION}

Many countries deliberately introduced systems of local government to ensure spot management of local problems. Municipal government and Panchayati Raj in India are illustrations of this type

\footnotetext{
*Assistant Professor, Department of Political Science, University of Burdwan, Burdwan, India
} E-mail: bappa_anil@rediffmail.com 


\section{Journal of Politics \& Governance, Vol. 8, No. 10, October 2020}

(Bhattacharya, 1981). To give a definition and specific meaning to the term 'local government' is a difficult task. The task becomes much more difficult when it takes into account a number of terms and phrases designed to connote more or less the same meaning, in spite of slight variation in regard to the structural patterns they imply; same of the popular terms are: 'local government', 'local authority', 'local self-government', 'local self-governing units' and 'local representative government' (Bhargava, 1965). Often the term 'local government' and 'local self-government' are used without any distinction. In India the term 'self-government' is more widely used and in other countries 'local government' is more prevalent (Rao, 1986). P. Stones define it by saying that 'local government is that part of government of a country which deals with those matters which concern people living in a particular locality' (Stones, 1963).

The local government is called the government at the local level simply because of the fact that conceptually, it has some inherent governmental characteristics which are: a) armed with popular mandate, it governs its locality or area as if they are normally elected by the local people, b) it works as a multipurpose institution delivering goods and services directly to the people, c) it enjoys Constitutional/legal status, and lastly, d) it works as a self-governing institution with autonomous status. Still the central government is a sovereign body while the local government is merely an autonomous institution.

The citizen participation is crucial for success of local government, which is also reflected as well as substantiated in various definitions of local government. Gluding defines local government as the management of their affairs by the people of locality (Goulding, 1970). In the word of Harris, it is a government of the people themselves through freely elected representative (Harris, 1949). J. S. Mill and Lord Bryce also emphasized the importance of local government because of its most conspicuous element that facilitates active participation of the people (Laski, 1961). As a matter of fact, local government is an expression, which has been used to denote several things, depending on the context. The connotation of local government establishes the crucial significance of participation of people in the management and administration of their local affairs through their elected representatives and their own frequent involvement in the formulation and implementation of development plans for their locality. Thus, it is obvious that the concept of people's participation in local government is of great importance for successful functioning of a local authority. People's participation not only enhances individual dignity and community feeling at the local levels, but also makes the programmes more responsive and better adapted to the local needs. People participation in local governance has also making a development communication between authority and mass, which helps us to better understanding about developmental process in grassroots level and also politics of development of rural area.

Panchayati Raj Institution in rural India for rural governance has a long history. It has it roots in ancient Indian administration. During ancient days, Indian village were organized in a way that enabled them to maintain social order through Panchayats. In the Vedic period, the village was the 'pivot' of administration. The village government was usually run under supervision and direct control by the village headman called 'Gramini'. In the Mauryan period, the village was the basic unit of administration and there was the existence of village Panchayat. In the Gupta period village council became the permanent feature of local administration. In the Chola period there was also the existence of well-organized village Panchayat system as such as modern Panchayat (Altekar, 1958). In Sultanate period Panchayat as a grassroots government looked after education, sanitation 


\section{Journal of Politics \& Governance, Vol. 8, No. 10, October 2020}

and acted as judicial body to settled disputes. In Mughal period the village administration by elders' council was made an indispensable part of the civil administration. It was autonomous in its own sphere and exercised powers in local taxation, administrative control etc. But there was no any evidence for the participation of women in such types of grassroots governmental bodies. After independence, persistent efforts were made in India to make rural local self-government visible and self-sustainable along the lines portrayed by Mahatma Gandhi. But unfortunately, the response of the State Government was of very different nature and as a result, the pace and pattern of establishment of rural local Political Institutions was not very enthusiastic in the initial phase. $73^{\text {rd }}$ Constitutional Amendment Act was passed in 1992 for the empowerment of grassroots democracy. After two and half decade of implementation of the $73^{\text {rd }}$ Constitution Amendment Act, it is evident from the grassroots experiences that the state acts have been amended from time to time to make it more effective in establishing Panchayati Raj Institutions as genuine structures of grassroots democracy. Through a system of reservation of $33 \%$ seats for women in local government has also been ensured in the states under this amendment act from the time of its implementation. The $73^{\text {rd }}$ Constitutional Amendment Act, 1992 gave ample scope for the empowerment of women through Panchayati Raj Institution. Gram Sabha have been bestowed with enormous power in the decisionmaking process under the 73rd Constitutional Amendment Act. In West Bengal, Gram Sansad at the Constituency/ward level of a Gram Panchayat is occupying important place in the decision-making processes under West Bengal Panchayat Amendment Act, 1994. Gram Sansad is a platform for common people both male and female in development communication in rural Bengal.

In West Bengal Panchayat Amendment Act, 1994, a Gram Sansad has been defined as "a body consisting of persons registered at any time in the electoral rolls pertaining to a constituency of a Gram Panchayat delineated for the purpose of last preceding general election to the Gram Panchayat". Thus, a meeting of Gram Sansad implies a meeting of all the electors of a constituency. In a sense, it is the legal entity at the grassroot level below the Gram Panchayat. Under the West Bengal Panchayat law, the Gram Panchayat is required to convene at least two meetings of every Sansad in a year, annual meeting in the month of May and half-yearly meeting in the month of November. The quorum of the Gram Sansad meeting is $10 \%$ and the meeting should be adjourned in absence of quorum. The adjourned meeting of Gram Sansad shall be held after seventh day at the same venue and at the same time and attendance of at least $5 \%$ members would make quorum.

\section{FUNCTION OF GRAM SANSAD}

The main function of Gram Sansad is to guide and advice the Gram Panchayat in regard to the schemes for economic development and social justice, identifications of beneficiaries of various poverty alleviation and food security programmes, constitution of one or more beneficiary committees for ensuring active participation of people in implementation, maintenance and equitable distribution of benefits of one or more schemes in its area. A Gram Sansad may raise objection to any action of Pradhan or any other member of Gram Panchayat for failure to implement any development work properly. Further it is mandatory for Gram Panchayat to place in the meetings of Gram Sansad the budget and audit report of the accounts of Gram Panchayat for deliberation, recommendation and suggestion of Gram Sansad.

The West Bengal Panchayat (Amendment) Act, 2003 has made it obligatory for a Gram Panchayat to act upon any recommendations of a Gram Sansad relating to prioritization of any list of beneficiaries or scheme or programme so far as it relates to the area of the Gram Sansad. However, if Gram 
Panchayats decides in a meeting that such recommendations are not acceptable or implementable under the existing provisions of the Act, rules or orders, such decision of the Gram Panchayat shall be placed in the next meeting of the Gram Sansad. From the view point of the functions and rules mentioned by West Bengal Panchayat Amendment Act 1994, Gram Sansad is main policy making institution in rural West Bengal. Due to the mandatory participation of common people Gram Sansad has plays an important role to making communication between individual, groups and authority. Gram Sansad has playing important role by making political socialized citizens for better understanding of developmental initiatives of states. Karl Deutsch is one of the foremost advocates of the communication theory. Karl Deutsch said that the political system, as the system of decision making and enforcement, can be seen as a network of communication channels (Roy, 2006). Gram Sansad as an institution of rural local grassroots governance has making decision as a developmental communication channels by inclusion of all section of people. Demands of various developmental issues arising in Gram Sansad from various channels such as individuals and groups. After receiving such issues through channels, Gram Sansad as a unit of developmental communication has making policy for development of grassroots. Under this developmental communication process local issues are raising and able to be gaining national importance. Politics of local level is also able to understand by this channel. Socialization regarding to developmental initiatives of a state is also understood by this institution. So, precondition of understanding on the developmental communication in local governance is community participation.

\section{OBJECTIVES OF THE STUDY}

1. To identify the nature of people participation in Gram Sansad;

2. To study the role of Gram Sansad in West Bengal as institution of rural local governance;

3. To understand the rural politics in Gram Sansad in Rampur I Gram Panchayat in particular and West Bengal in general;

4. To identify the nature of developmental communication in rural grassroots institution.

\section{Research Questions}

1. What is the nature of people participation in Gram Sansad?

2. What is the role of Gram Sansad in West Bengal as an institution of rural local governance?

3. What is the nature of rural politics in the Gram Sansad?

4. What is the nature of developmental communication in rural grassroots institution?

\section{METHODOLOGY}

The main focus is the Gram Sansad with in the Panchayati Raj System in Cooch Behar district of West Bengal. The major concern here is to explore the nature of people participation in Gram Sansad. As a grassroots institution, Gram Sansad has playing an important role to making communication between mass, mass and authority for better understanding on rural politics. For this aims this paper has trying to explore the nature of people participation and communication channel in Gram Sansad. From the view point researcher has choosing Cooch Behar district of West Bengal as a sample for the study of actual reality by using purposive sampling. Researcher select Cooch Behar district out of 20 districts because, this is the farthest district from the state head quarter. Another reason is it is a scheduled cast populated district in the country where more than $50 \%$ are scheduled cast people are living. Another cause is that this district is socio-economically backward district was declared by the government. All 11 Gram Sansad from Rampur I Gram Panchayat of Cooch Behar district are selected purposely for the micro level study. Behind the logic of the selection of Rampur I Gram 
Panchayat is the Panchayat is situated in the state boundary of State of Assam and Alipurduar district of West Bengal. Another logic is that the Gram Panchayat is the farthest more Gram Panchayat from the district headquarter and people of the localities are dependent on agriculture for their livelihood. So, researcher select the area as study area for better understanding on the rural politics and developmental communication. Researcher personally attended in Eleven Gram Sansad meetings since 2002 to 2008 for observations. Researcher also collects official documents of Gram Sansad meetings from respective GP office. Finally, it is said that researcher has collected primary data from respective Sansad areas through interviews and observations and collect secondary data from the record books of the Gram Sansads of respective Gram Panchayat office. Researcher also reviewed various published works related to Gram Sansad as secondary data source. After collection of data researcher has using simple statistical tools for drawing result.

\section{PEOPLE'S PARTICIPATION IN GRAM SANSAD}

Researcher conducted a field study regarding people participation in Gram Sansad and understanding on development communication in grassroots level in Rampur-I Gram Panchayat. In this regard researcher studied people's participation in the Gram Sansad, during the year of 2003-04 to 2005-06. During that period, the Gram Panchayats organized three half yearly meetings and three annual meeting in all 11 Gram Sansad of Rampur I Gram Panchayat area.

Table 1 is showing the attendance of participants including male \& female during the period of 200304 to 2005-06 of half-yearly meetings. Table 2 is showing the attendance of participants including male and female during the period of 2003-04 to 2005-06 of yearly meetings.

Table 1: Half Yearly Attendance Report

\begin{tabular}{|c|c|c|c|c|c|c|c|c|c|c|}
\hline \multirow{2}{*}{$\begin{array}{l}\text { Sansad Name } \\
\& \text { No. }\end{array}$} & \multirow{2}{*}{$\begin{array}{l}\text { Total } \\
\text { Voter }\end{array}$} & \multicolumn{3}{|c|}{ 2003-04 } & \multicolumn{3}{|c|}{ 2004-05 } & \multicolumn{3}{|c|}{$2005-06$} \\
\hline & & Male & Female & Total & Male & Female & Total & Male & Female & Total \\
\hline $\begin{array}{l}\text { Parchim } \\
\text { Rampur (82) }\end{array}$ & 1161 & $\begin{array}{l}90 \\
(63 \%)\end{array}$ & $\begin{array}{l}53 \\
(37 \%)\end{array}$ & $\begin{array}{l}143 \\
(12 \%)\end{array}$ & $\begin{array}{l}181 \\
(81 \%)\end{array}$ & $\begin{array}{l}42 \\
(19 \%)\end{array}$ & $\begin{array}{l}223 \\
(19 \%)\end{array}$ & $\begin{array}{l}167 \\
(72 \%)\end{array}$ & $\begin{array}{l}66 \\
(28 \%)\end{array}$ & $\begin{array}{l}233 \\
(20 \%)\end{array}$ \\
\hline $\begin{array}{l}\text { Parchim } \\
\text { Rampur (87) }\end{array}$ & 550 & $\begin{array}{l}84 \\
(79 \%)\end{array}$ & $\begin{array}{l}22 \\
(21 \%)\end{array}$ & $\begin{array}{l}106 \\
(19 \%)\end{array}$ & $\begin{array}{l}125 \\
(61 \%)\end{array}$ & $\begin{array}{l}80 \\
(39 \%)\end{array}$ & $\begin{array}{l}205 \\
(37 \%)\end{array}$ & $\begin{array}{l}57 \\
(51 \%)\end{array}$ & $\begin{array}{l}55 \\
(49 \%)\end{array}$ & $\begin{array}{l}112 \\
(20 \%)\end{array}$ \\
\hline $\begin{array}{l}\text { Parchim } \\
\text { Rampur (88) }\end{array}$ & 1023 & $\begin{array}{l}95 \\
(52 \%)\end{array}$ & $\begin{array}{l}86 \\
(48 \%)\end{array}$ & $\begin{array}{l}181 \\
(18 \%)\end{array}$ & $\begin{array}{l}116 \\
(73 \%)\end{array}$ & $\begin{array}{l}43 \\
(27 \%)\end{array}$ & $\begin{array}{l}159 \\
(16 \%)\end{array}$ & $\begin{array}{l}74 \\
(50 \%)\end{array}$ & $\begin{array}{l}75 \\
(50 \%)\end{array}$ & $\begin{array}{l}149 \\
(15 \%)\end{array}$ \\
\hline \multirow[t]{2}{*}{$\begin{array}{l}\text { Uttar Rampur } \\
\text { (89) }\end{array}$} & 1194 & $\begin{array}{l}37 \\
(63 \%)\end{array}$ & $\begin{array}{l}22 \\
(37 \%)\end{array}$ & $\begin{array}{l}59 \\
(5 \%)\end{array}$ & \multirow[t]{2}{*}{$\begin{array}{l}135 \\
(58 \%)\end{array}$} & \multirow[t]{2}{*}{$\begin{array}{l}101 \\
(42 \%)\end{array}$} & \multirow[t]{2}{*}{$\begin{array}{l}236 \\
(20 \%)\end{array}$} & \multirow[t]{2}{*}{$\begin{array}{l}150 \\
(63 \%)\end{array}$} & \multirow[t]{2}{*}{$\begin{array}{l}85 \\
(37 \%)\end{array}$} & \multirow[t]{2}{*}{$\begin{array}{l}235 \\
(20 \%)\end{array}$} \\
\hline & & $\begin{array}{l}78 \\
(59 \%)\end{array}$ & $\begin{array}{l}55 \\
(41 \%)\end{array}$ & $\begin{array}{l}133 \\
(11 \%)\end{array}$ & & & & & & \\
\hline $\begin{array}{l}\text { Uttar Rampur } \\
\text { (90) }\end{array}$ & 504 & $\begin{array}{l}64 \\
(86 \%)\end{array}$ & $\begin{array}{l}10 \\
(14 \%)\end{array}$ & $\begin{array}{l}74 \\
(15 \%)\end{array}$ & $\begin{array}{l}46 \\
(69 \%)\end{array}$ & $\begin{array}{l}21 \\
(31 \%)\end{array}$ & $\begin{array}{l}67 \\
(13 \%)\end{array}$ & $\begin{array}{l}699 \\
(73 \%)\end{array}$ & $\begin{array}{l}26 \\
(27 \%)\end{array}$ & $\begin{array}{l}95 \\
(19 \%)\end{array}$ \\
\hline $\begin{array}{l}\text { Parchim } \\
\text { Rampur (91) }\end{array}$ & 635 & $\begin{array}{l}82 \\
(75 \%)\end{array}$ & $\begin{array}{l}28 \\
(25 \%)\end{array}$ & $\begin{array}{l}110 \\
(17 \%)\end{array}$ & $\begin{array}{l}50 \\
(47 \%)\end{array}$ & $\begin{array}{l}62 \\
(53 \%)\end{array}$ & $\begin{array}{l}112 \\
(18 \%)\end{array}$ & $\begin{array}{l}64 \\
(71 \%)\end{array}$ & $\begin{array}{l}26 \\
(29 \%)\end{array}$ & $\begin{array}{l}90 \\
(14 \%)\end{array}$ \\
\hline Madhya & 1093 & 101 & 17 & 118 & 110 & 58 & 168 & 101 & 86 & 187 \\
\hline
\end{tabular}


Journal of Politics \& Governance, Vol. 8, No. 10, October 2020

\begin{tabular}{|l|l|l|l|l|l|l|l|l|l|l|}
\hline Rampur (92) & & $(86 \%)$ & $(14 \%)$ & $(11 \%)$ & $(65 \%)$ & $(35 \%)$ & $(15 \%)$ & $(54 \%)$ & $(46 \%)$ & $(17 \%)$ \\
\hline $\begin{array}{l}\text { Naziran } \\
\text { Deautikhata } \\
(93)\end{array}$ & 1043 & $\begin{array}{l}77 \\
(66 \%)\end{array}$ & $\begin{array}{l}39 \\
(34 \%)\end{array}$ & $\begin{array}{l}116 \\
(11 \%)\end{array}$ & $\begin{array}{l}72 \\
(59 \%)\end{array}$ & $\begin{array}{l}50 \\
(41 \%)\end{array}$ & $\begin{array}{l}122 \\
(11 \%)\end{array}$ & $\begin{array}{l}66 \\
(55 \%)\end{array}$ & $\begin{array}{l}56 \\
(45 \%)\end{array}$ & $\begin{array}{l}122 \\
(11 \%)\end{array}$ \\
\hline $\begin{array}{l}\text { Naziran } \\
\text { Deautikhata } \\
(94)\end{array}$ & 1089 & $\begin{array}{l}143 \\
(75 \%)\end{array}$ & $\begin{array}{l}48 \\
(25 \%)\end{array}$ & $\begin{array}{l}191 \\
(18 \%)\end{array}$ & $\begin{array}{l}127 \\
(62 \%)\end{array}$ & $\begin{array}{l}79 \\
(38 \%)\end{array}$ & $\begin{array}{l}206 \\
(19 \%)\end{array}$ & $\begin{array}{l}83 \\
(59 \%)\end{array}$ & $\begin{array}{l}58 \\
(41 \%)\end{array}$ & $\begin{array}{l}141 \\
(13 \%)\end{array}$ \\
\hline $\begin{array}{l}\text { Chatt Bhalka } \\
(95)\end{array}$ & 962 & $\begin{array}{l}188 \\
(90 \%)\end{array}$ & $\begin{array}{l}20 \\
(10 \%)\end{array}$ & $\begin{array}{l}208 \\
(22 \%)\end{array}$ & $\begin{array}{l}245 \\
(91 \%)\end{array}$ & $\begin{array}{l}25 \\
(9 \%)\end{array}$ & $\begin{array}{l}270 \\
(28 \%)\end{array}$ & $\begin{array}{l}95 \\
(57 \%)\end{array}$ & $\begin{array}{l}73 \\
(43 \%)\end{array}$ & $\begin{array}{l}168 \\
(18 \%)\end{array}$ \\
\hline $\begin{array}{l}\text { Chatt Bhalka } \\
(96)\end{array}$ & 715 & $\begin{array}{l}96 \\
(89 \%)\end{array}$ & $\begin{array}{l}12 \\
(11 \%)\end{array}$ & $\begin{array}{l}108 \\
(15 \%)\end{array}$ & $\begin{array}{l}81 \\
(59 \%)\end{array}$ & $\begin{array}{l}56 \\
(41 \%)\end{array}$ & $\begin{array}{l}137 \\
(19 \%)\end{array}$ & 81 & $\begin{array}{l}66 \\
(44 \%)\end{array}$ & $\begin{array}{l}147 \\
(21 \%)\end{array}$ \\
\hline
\end{tabular}

*N.B - Adjourned meetings s(Source: Rampur I Gram Panchayat)

Table 1 is showing the attendance of peoples' in half yearly Gram Sansad meetings. People's participation is very important for the success of grassroots democracy. Every voters of respective Gram Sansad is members of the respective Gram Sansad. So, it is provision that every voter of a respective Sansad to participates in Sansad meeting for better planning of necessary projects and its implementation. Mass participation in meeting has making a developmental communication channel between members of the Sansad and government which helps to policy makers to planning for need based programme by utilizing local resources available in the respective area. Within the developmental communication in Gram Sansad, political culture of the mass is observed by state through political parties and government. This institution has plying important role to socialize its members within the political culture of respective political system. People are able to aware about the culture of political system where they are living by their participation in Gram Sansad meeting. But the table is showing the participation of people both male and female is very low in every halfyearly meeting during that period. Women participation is too trivial than male participation in the meeting during that period. Participation data of all Gram Sansad's meeting is showing very low during the half-yearly meetings of 2003-04.

Highest number of people only 208 out of 962 voters presented in Sansad meeting in Chatt Bhalka (95) in 2003-04. The highest number of women participated in the half yearly Sansad meeting in Parchim Rampur (88), which is $48 \%$, but total number is only 86 during 2003-04. The lowest number of people participated in the meeting of Uttar Rampur (89) is only 59 (5\%) out of its total 1194 population and the meeting is adjourned due to the lack of quorum. The lowest number of women participated in Sansad meeting of Chatt Bhalka (95) Sansad, which is only $10 \%$ of total population. Highest number of people participated in Parchim Rampur (87) Sansad meeting which is 205 (37\%) out of total voters 550 and lowest number of voters only 122 (11\%) out of total voters 1043 was presents in Naziran Deutikhata (93) Sansad meeting. In 2004-05 highest numbers of women participated in Parchim Rampur (91) Sansad meeting, which is 62 (53\%) out of 112 participants and lowest numbers of women participated in Chatt Bhalka (95) Sansad meeting which is only 25 (9\%) out of total 207 participants. Highest number of people 147 (21\%) out of 715 voters is participated in Chatt Bhalka (96) Gram Sansad meeting in 2005-06 and lowest participation is recorded from Naziran Deautikhata (93) Sansad meeting which is only 122 (11\%) out of 1043 voters. In 2005-06 highest women participation is recorded from Parchim Rampur (88) Sansad meeting which is $75(50 \%)$ out of total 149 participants and lowest women participation is recorded from Uttar 
Rampur (90) Sansad meeting which is 26 (27\%) out of total 95 participants. Above observation showing that people participation in all half-yearly meetings in Gram Sansads is very poor. Women participation is also very much poor than male participation in all half-yearly meeting; although male participation is not much higher than women participation. But participation is able to ensure developmental communication among mass, mass and individual, mass with state.

Table 2: Yearly Attendance Report

\begin{tabular}{|c|c|c|c|c|c|c|c|c|c|c|}
\hline \multirow{2}{*}{$\begin{array}{l}\text { Sansad } \\
\text { Name \& No. }\end{array}$} & \multirow{2}{*}{$\begin{array}{l}\text { Total } \\
\text { Voter }\end{array}$} & \multicolumn{3}{|c|}{ 2003-04 } & \multicolumn{3}{|c|}{ 2004-05 } & \multicolumn{3}{|c|}{$2005-06$} \\
\hline & & Male & Female & Total & Male & Female & Total & Male & Female & Total \\
\hline $\begin{array}{l}\text { Parchim } \\
\text { Rampur (82) }\end{array}$ & 1161 & $\begin{array}{l}107 \\
(70 \%) \\
\end{array}$ & $\begin{array}{l}46 \\
(30 \%) \\
\end{array}$ & $\begin{array}{l}153 \\
(13 \%) \\
\end{array}$ & $\begin{array}{l}109 \\
(70 \%) \\
\end{array}$ & $\begin{array}{l}47 \\
(30 \%) \\
\end{array}$ & $\begin{array}{l}156 \\
(13 \%) \\
\end{array}$ & $\begin{array}{l}152 \\
(68 \%) \\
\end{array}$ & $\begin{array}{l}71 \\
(32 \%) \\
\end{array}$ & $\begin{array}{l}223 \\
(20 \%) \\
\end{array}$ \\
\hline $\begin{array}{l}\text { Parchim } \\
\text { Rampur (87) }\end{array}$ & 550 & $\begin{array}{l}93 \\
(82 \%) \\
\end{array}$ & $\begin{array}{l}20 \\
(18 \%) \\
\end{array}$ & $\begin{array}{l}113 \\
(21 \%) \\
\end{array}$ & $\begin{array}{l}111 \\
(71 \%) \\
\end{array}$ & $\begin{array}{l}45 \\
(29 \%) \\
\end{array}$ & $\begin{array}{l}156 \\
(28 \%) \\
\end{array}$ & $\begin{array}{l}86 \\
(70 \%) \\
\end{array}$ & $\begin{array}{l}37 \\
(30 \%) \\
\end{array}$ & $\begin{array}{l}123 \\
(22 \%) \\
\end{array}$ \\
\hline $\begin{array}{l}\text { Parchim } \\
\text { Rampur (88) }\end{array}$ & 1023 & $\begin{array}{l}97 \\
(72 \%) \\
\end{array}$ & $\begin{array}{l}37 \\
(28 \%) \\
\end{array}$ & $\begin{array}{l}134 \\
(13 \%) \\
\end{array}$ & $\begin{array}{l}89 \\
(67 \%) \\
\end{array}$ & $\begin{array}{l}44 \\
(33 \%) \\
\end{array}$ & $\begin{array}{l}133 \\
(13 \%) \\
\end{array}$ & $\begin{array}{l}112 \\
(73 \%) \\
\end{array}$ & $\begin{array}{l}41 \\
(27 \%) \\
\end{array}$ & $\begin{array}{l}153 \\
(15 \%) \\
\end{array}$ \\
\hline $\begin{array}{l}\text { Uttar } \\
\text { Rampur (89) }\end{array}$ & 1194 & $\begin{array}{l}98 \\
(64 \%) \\
\end{array}$ & $\begin{array}{l}54 \\
(36 \%) \\
\end{array}$ & $\begin{array}{l}152 \\
(13 \%) \\
\end{array}$ & $\begin{array}{l}101 \\
(67 \%) \\
\end{array}$ & $\begin{array}{l}50 \\
(33 \%) \\
\end{array}$ & $\begin{array}{l}151 \\
(13 \%) \\
\end{array}$ & $\begin{array}{l}104 \\
(68 \%) \\
\end{array}$ & $\begin{array}{l}50 \\
(32 \%) \\
\end{array}$ & $\begin{array}{l}154 \\
(13 \%) \\
\end{array}$ \\
\hline $\begin{array}{l}\text { Uttar } \\
\text { Rampur (90) }\end{array}$ & 504 & $\begin{array}{l}65 \\
(81 \%) \\
\end{array}$ & $\begin{array}{l}15 \\
(19 \%) \\
\end{array}$ & $\begin{array}{l}80 \\
(16 \%) \\
\end{array}$ & $\begin{array}{l}69 \\
(75 \%) \\
\end{array}$ & $\begin{array}{l}23 \\
(25 \%) \\
\end{array}$ & $\begin{array}{l}92 \\
(18 \%) \\
\end{array}$ & $\begin{array}{l}68 \\
(80 \%) \\
\end{array}$ & $\begin{array}{l}17 \\
(20 \%) \\
\end{array}$ & $\begin{array}{l}85 \\
(17 \%) \\
\end{array}$ \\
\hline $\begin{array}{l}\text { Parchim } \\
\text { Rampur (91) }\end{array}$ & 635 & $\begin{array}{l}88 \\
(74 \%)\end{array}$ & $\begin{array}{l}31 \\
(26 \%)\end{array}$ & $\begin{array}{l}119 \\
(19 \%)\end{array}$ & $\begin{array}{l}57 \\
(70 \%)\end{array}$ & $\begin{array}{l}24 \\
(30 \%)\end{array}$ & $\begin{array}{l}81 \\
(13 \%)\end{array}$ & $\begin{array}{l}64 \\
(73 \%)\end{array}$ & $\begin{array}{l}24 \\
(27 \%)\end{array}$ & $\begin{array}{l}88 \\
(14 \%)\end{array}$ \\
\hline $\begin{array}{l}\text { Madhya } \\
\text { Rampur (92) }\end{array}$ & 1093 & $\begin{array}{l}119 \\
(88 \%)\end{array}$ & $\begin{array}{l}16 \\
(12 \%)\end{array}$ & $\begin{array}{l}135 \\
(12 \%)\end{array}$ & $\begin{array}{l}102 \\
93 \%)\end{array}$ & $\begin{array}{l}08 \\
(7 \%)\end{array}$ & $\begin{array}{l}110 \\
(10 \%)\end{array}$ & $\begin{array}{l}109 \\
(75 \%)\end{array}$ & $\begin{array}{l}37 \\
(25 \%)\end{array}$ & $\begin{array}{l}146 \\
(13 \%)\end{array}$ \\
\hline $\begin{array}{l}\text { Naziran } \\
\text { Deautikhata } \\
\text { (93) }\end{array}$ & 1043 & $\begin{array}{l}90 \\
(58 \%)\end{array}$ & $\begin{array}{l}64 \\
(42 \%)\end{array}$ & $\begin{array}{l}154 \\
(15 \%)\end{array}$ & $\begin{array}{l}88 \\
(73 \%)\end{array}$ & $\begin{array}{l}33 \\
(27 \%)\end{array}$ & $\begin{array}{l}121 \\
(11 \%)\end{array}$ & $\begin{array}{l}71 \\
(62 \%)\end{array}$ & $\begin{array}{l}44 \\
(38 \%)\end{array}$ & $\begin{array}{l}115 \\
(11 \%)\end{array}$ \\
\hline $\begin{array}{l}\text { Naziran } \\
\text { Deautikhata } \\
(94)\end{array}$ & 1089 & $\begin{array}{l}143 \\
(68 \%)\end{array}$ & $\begin{array}{l}67 \\
(32 \%)\end{array}$ & $\begin{array}{l}210 \\
(19 \%)\end{array}$ & $\begin{array}{l}118 \\
(69 \%)\end{array}$ & $\begin{array}{l}60 \\
(31 \%)\end{array}$ & $\begin{array}{l}178 \\
(16 \%)\end{array}$ & $\begin{array}{l}91 \\
(58 \%)\end{array}$ & $\begin{array}{l}67 \\
(42 \%)\end{array}$ & $\begin{array}{l}158 \\
(15 \%)\end{array}$ \\
\hline $\begin{array}{l}\text { Chatt Bhalka } \\
\text { (95) }\end{array}$ & 962 & $\begin{array}{l}133 \\
(75 \%)\end{array}$ & $\begin{array}{l}44 \\
(25 \%)\end{array}$ & $\begin{array}{l}177 \\
(18 \%)\end{array}$ & $\begin{array}{l}28^{*} \\
(58 \%)\end{array}$ & $\begin{array}{l}20 * \\
(42 \%)\end{array}$ & $\begin{array}{l}48 * \\
(5 \%)\end{array}$ & $\begin{array}{l}130 \\
(80 \%)\end{array}$ & $\begin{array}{l}33 \\
(20 \%)\end{array}$ & $\begin{array}{l}163 \\
(17 \%)\end{array}$ \\
\hline $\begin{array}{l}\text { Chatt Bhalka } \\
\text { (96) }\end{array}$ & 715 & $\begin{array}{l}121 \\
(79 \%)\end{array}$ & $\begin{array}{l}32 \\
(21 \%)\end{array}$ & $\begin{array}{l}153 \\
(21 \%)\end{array}$ & $\begin{array}{l}107 \\
(88 \%)\end{array}$ & $\begin{array}{l}15 \\
(12 \%)\end{array}$ & $\begin{array}{l}122 \\
(17 \%)\end{array}$ & $\begin{array}{l}80 \\
(58 \%)\end{array}$ & $\begin{array}{l}58 \\
(42 \%)\end{array}$ & $\begin{array}{l}138 \\
(19 \%)\end{array}$ \\
\hline
\end{tabular}

*N.B - Adjourned meeting (Source: Rampur I Gram Panchayat)

Table 2 is showing the attendance of peoples' in yearly Gram Sansad meetings of Rampur-1 Gram Panchayat of Coochbehar district of West Bengal. People's participation in Gram Sansad is very much important for the success of grassroots democracy. The platform of common people in rural administration, like as Gram Sabha and Gram Sansad is very important place for policy formulation and taking decision for policy implementation. Gram Sansad has plying the role of watchdog in policy implementation by maintaining transparency in rural governance. So, people's participation in Gram Sansad is very much important for the empowerment of democracy and the empowerment of weaker section of society by developmental communication. But the table showing the participation 


\section{Journal of Politics \& Governance, Vol. 8, No. 10, October 2020}

of people both male and female is very low. Women participation is very much low compared to male participation in every meeting during that period.

Women participation in yearly Sansad meetings in all Gram Sansad's during the year 2003-04 is showing very low compared to male participation. In 2003-04, highest people participated in the yearly Gram Sansad meeting in Parchim Rampur (87) and Chatt Bhalka (96) jointly; Parchim Rampur recorded 113 (21\%) out of total voters 550 and Chatt Bhalka recorded 153 (21\%) out of 715 total voters and lowest number of people only $135(12 \%)$ is present out of total 1093 voters in Madhya Rampur Gram Sansad meeting in 2003-04 period. During that period highest women 64 (42\%) in number is participated in Naziran Deautikhata (93) Sansad meeting and lowest women participation which is only 16 (12\%) out of total 135 participants is recorded from the Madhya Rampur (92) Sansad meeting. In 2004-05, highest number of people $156(28 \%)$ out of 550 is present in Parchim Rampur (87) Sansad meeting and lowest number of people only $48(5 \%)$ is present in Chatt Bhalka (95) Sansad meeting. Highest number women $20(42 \%)$ in number is present out of total participants of 48 in Chatt Bhalka (95) Sansad meeting and lowest women only 08 (7\%) out of 110 is present in Madhya Rampur (92) Gram Sansad. In 2005-06, highest number of people 123 (22\%) out of total voter 550 is present in Parchim Rampur (87) Sansad meeting and lowest number of participants 115 (11\%) in number out of 1043 voters is present in Naziran Deautikhata (93) Sansad meeting. Highest number of women present in the Sansad meetings of Chatt Bhalka (96) and Naziran Deautikhata (94) jointly, which is 58 (42\%) out of total 138 participants and 67 (42\%) out of total 158 participants respectively. Lowest number of women present in the Sansad meetings in Chatt Bhalka (95) and Uttar Rampur (90) jointly, which is 33 (20\%) out of total 163 participants and 17 (20\%) out of total 85 participants respectively. Researcher's observation is that people participation in all yearly meetings during that period is very much low. Women participation in grassroots democracy is not hopeful; their participation is too much lower than male participation.

People participation data of Gram Sansad meetings during 2003-04 to 2005-06 is showing is very much lower in every yearly and half-yearly meeting. But participation is precondition for the success of the grassroots institution. Due to lack of mass participation developmental communication initiatives is not working. Most of the participants are not active participant; they are sitting in meeting only hearing the leaders of ruling party. Participants are passive listener, so local leaders of ruling party have always playing their party card in the meeting. Local leaders are open threatens to the supporters of opposition parties. So, supporters other than ruling party are not present in the Sansad meeting. Due to the over control of ruling party, Gram Sansad of West Bengal has lost its importance within the common people of villages. Gram Sansad meeting always turn to the ruling party meeting ignoring its role to the society. Common people are not able to rise their voice in meeting due to the over control of local political leaders. If, someone, except ruling party supporter is raising his or her demand to the meeting is always dismiss by the leaders. So actual politicocultural socialization of the mass is always has been unfulfilled dream due to lack of cooperation between all sections of the people of rural areas. Rural India sinking in narrow politics till date, so fruits of development is not reached to the actual beneficiaries. Bottom up approach is recognized but top down approach is followed till the day in developmental planning. So, in this backdrop developmental communication is hampered and rural people are deepening in narrow rural politics. 


\section{Journal of Politics \& Governance, Vol. 8, No. 10, October 2020}

\section{CONCLUSION}

Meeting of Gram Sansad is an important platform for the inclusion of rural people in decision making process. Gram Sansad is a place; where common people of a respective Sansad can be able to takes part in decision-making and implementation processes. Mass participation in Gram Sansad can make leadership within the people of rural area, which is very important for the development of locality. Mass participation and their inclusion in decision making processes has creates a developmental communication channel between general people and government/state, general people and political leaders, individuals and groups, which is precondition for the development of a community by developing their surrounding environment. Government of India has taken various initiatives for empowering rural people by inclusion of them in decision making process through institutionalization of local rural government under $73^{\text {rd }}$ Constitutional Amendment Act in 1992. Gram Sabha a people institution of rural India has been bestowed with enormous power in the decision making process under the 73rd Constitutional Amendment Act in 1992. In West Bengal decentralized institution named as Gram Sansad set up below the Gram Sabha level in each and every Sansad area of each and every Gram Panchayat under West Bengal Panchayat Amendment Act, 1994.

Gram Sansad as a platform for common people of rural West Bengal has playing important role in rural development by empowering mass since its initiation in the arena of development communication. Structurally the institution is very strong, but due to the lack of good will of political parties and its leaders the institution now suffering for its existence. Neither political leaders nor bureaucrats wanted to successfully run the institution; so, the institution is not gain status of people institution. They never want to transfer the power from their hands to grassroots people; but Constitution has provisions to devolution of power from the top to bottom. In this juncture the institution just lost its importance to the mass because they realize that it is not able to fulfill their long-awaited dream. On the other hand, apprehension of rural political leaders is that if people of grassroots are able to understand their own rights and their importance in policy making then leaders have lost their domination on rural mass. So due to the fear of losing their domination on all rural activities they always try to control the meeting by using their political card. But there is ample scope in the institution for the development of rural areas by inclusion of vulnerable people. But due to narrow rural politics of ruling party the institution is now running as like as malnourished human being. After initiation of Gram Sansad in rural Bengal as grassroots institution it is running ups and down situation. From 2002 to 2006, Gram Sansad was playing important role in rural decisionmaking process in rural Bengal. But after 2006 this grassroots institution has lost its importance due to narrow party politics in rural Bengal. Very recently Trinamul Congress government of West Bengal has taking some initiative for the reviving of the institution in rural Bengal for the balance development of rural areas.

However, TMC-led West Bengal Government has not given due importance on the institution in the first phase of her governance. So now Gram Sansad of West Bengal running irregularly likes as boon less existence. Now people are not interested to participate in the meeting of the Gram Sansad due to its non-functioning feature. But the concept has great importance for the understanding of rural reality. Inclusive rural development is possible only by the strengthening of the institution. Strengthening of the institution is very necessary by discarding all political and bureaucratic hegemony for the transparent and accountable governance in rural area and also better understanding of rural life. If political parties are taking positive role discarding by voting politics for 
the interest of common people, then it would able to empower grassroots democracy which are the back boon of rural development. It is very necessary to de-bureaucratization in grassroots level for the real empowerment of rural beneficiaries. Gram Sansad as a people forum and the place of direct democracy has taking important role for overall development of rural society since its birth and hope it would able to take important role for the empowerment of rural vulnerable people by strengthening developmental communication.

\section{REFERENCE}

Bhattacharya, M. (1981). Approaches to the study of local government. The Calcutta Journal of Political Studies, 1 (2), pp. 75.

Bhargava, B. S. (1965). Local government and national development. Political Scientist, 2 (1).

Rao, N. R. (1986). Municipal Finance in India. New Delhi: Inter India Publications.

Stones, P. (1963). Local government for students. London: Macdonald and Evans Ltd.

Goulding, L. (1970). Local government, London: St. Paul's House.

Harris, G. M. (1949). Comparative local government, London: Oxford.

Laski, H. (1961). A grammar of politicos. London: Gorge Allen and Unwin.

Altekar, A. S. (1958). State and government in ancient India. Delhi: Motilal Banarsidass Publishers \& Booksellers.

Roy, S. N. (2006). Modern comparative politics appraaches, methods and issues. New Delhi: Prentice Hall of India.

Aiyar, M. S. (2007). A social revolution: Panchayati raj. Kurukshetra, 55.

Lieten, G. K. (1994). Developement, devolution and democracy: Village discourse in West Bengal. New Delhi: Sage.

Singh, S. Y. (2006). People's participation in gram sabha: A case study of rural Madhay Pradesh. Kurukshetra, 54. 